\title{
Senator John F. Kennedy: Anti-Imperialism and Utopian Deficit
}

\author{
ANDERS STEPHANSON
}

Opinions of John F. Kennedy differ but it is commonly agreed that he was an impatient man and easily bored (though when he was laid up lengthily in a hospital bed, which happened not infrequently, his stoicism and patience were nothing short of astonishing). It stands to reason, then, that one of the things that bored him in the I950s was the cold war, by then solidified into a dogmatic and rigid system. ${ }^{\mathrm{I}}$ It is the ideological nature of that boredom, or discomfort, its dilemmas and limits, that interest me here. My double wager is that if one pursues Kennedy's idiosyncrasies on this score without reading him backwards from the unflinching coldwar policies he actually launched, apparently, in his presidency, then one will learn something both about the cold war at the time and about Kennedy himself.

Idiosyncrasy, of course, never became apostasy. Kennedy would not have been elected President had that been the case. ${ }^{2}$ Arguably, the surviving coldwar thematic within his posture - the militancy, if you will - became more pronounced as he got closer to the election. That option was always a possibility in his own 'system' (or set of gestures) as it evolved in the mid-r 950s. Nevertheless, his position featured throughout a studied ambiguity whereby vibrant

Department of History, Columbia University. Email: ags8@columbia.edu. Many thanks to David Fine and Joshua Fattal, who helped with the research; to Marilyn Young for always being a stern and fair critic; to Ann Douglas for interesting conversation; and to Scott Lucas and Bevan Sewall and the British Association for American Studies for inviting me to give the address on which the article is based.

'When used as an attribute, the cold war is rendered "coldwar"; and the noun itself is never capitalized. Here I am following the rule laid down for me in no uncertain terms by the late and lamented Craig Owens, who, among many things, was a stellar editor when he was at Art in America. I have followed the same procedure with "the third world."

${ }^{2}$ Thus he could never have gone as far as George F. Kennan, alleged "architect of containment," who did in fact became an apostate in the I950s, confronting directly the whole coldwar axiomatic. Kennedy read Kennan but prudently kept him at a distance, fobbing him off in 1961 with the ambassadorship to Tito's Yugoslavia. 
calls for more and better efforts in the competition with the Soviet Union would typically be coupled with similarly strong appeals to keeping that competition within a peaceful frame, at the same time as he would insist that the epochal antagonism should in no way be the sum total of what the United States ought to do in the world and certainly not what was necessarily decisive about any given event. This "pragmatic" critique of the cold war as totality, as closure, is worth consideration, if nothing else precisely because of its ultimate impossibility but also because what followed is not exactly what it seems. The degree to which the cold warrior of I96I was an overdetermined figure is thus open to debate; he himself somehow seemed to sense in his more dialectical moments that one would have to go through rather than confront a certain "present" in order to displace and transcend it. One might then, however, also argue that he never intended that invigorated coldwar struggle to be a cold war at all, at least not in the sense of orthodoxy. ${ }^{3}$

The substantial part of his critique had to do with "imperialism" anticolonial liberation was the wave, not only of the future but of the present, which would have happened with or without communism, and the United States should not subordinate its support for that wave to its coldwar concerns by supporting, in effect, the colonial powers of Western Europe just because they also happened to be allies in NATO. Those "allies" turned out in practical terms to be only one ally, namely France, whose imperial wars in Vietnam and then Algeria became salient targets for Kennedy in some of the most important acts he ever performed in his relatively short career as a Senator. There was, however, also a procedural part to his dissatisfaction:

\footnotetext{
${ }^{3}$ Kennedy said little systemically about the cold war, in part because there was no gain in doing so, partly because of the genuine difficulties, both conceptual and political. One intriguing "dialectical" remark he made is reported by Harris Wofford: "The key thing for the country is a new foreign policy that will break out of the confines of the cold war. Then we can build a decent relationship with the developing nations and begin to respond to their needs. We can stop the vicious circle of the arms race and promote diversity and peaceful change within the Soviet bloc." Wofford was an adviser in the 1960 campaign, a specialist on civil rights and also part of organizing the Peace Corps. See Harris Wofford, Of Kennedys and Kings: Making Sense of the Sixties (New York: Farrar, Straus, Giroux, 1980), 36-37. The quotation is indirectly rendered but rings quite true. We need to end "the frozen, belligerent brink-of-war phase of the long Cold War," as he also said. The phase, but not the war? one might ask. See his speech at Rochester, I Oct. 1959, reprinted in John F. Kennedy, Strategy for Peace, ed. Allan Nevins (New York: Popular Library, 1960), 37. Around 1960, too, he would sometimes refer in an offhanded manner to Arnold Toynbee's notion that the cold war might turn into the kind of long-term truce and acceptance that eventually came to mark the relationship between Islam and Christianity, two other all-or-nothing positions analogous to the contemporary East-West antagonism. See e.g. his speech at South Eugene, OR, 22 April 1960, at www.jfklibrary.org/Research/Research-Aids/JFK-Speeches/South-EugeneOR_19600422.aspx. A large number of his speeches from 1960 have been digitized by the John F. Kennedy Library (henceforth JFKL), far fewer for the preceding years.
} 
orthodoxy, whatever its actual content as a set of propositions, constrained leadership and action, the ability to wield power for whatever ends in an intelligent way.

A symptomatic reading of this presupposes, then, some kind of concept of the cold war as orthodoxy, as US orthodoxy, against which Kennedy's alternative, deliberately inchoate and ambiguous as it ultimately proved, can be gauged. Before I offer such a sketch, however, two things should summarily be addressed: historiography and biography. First, there is a mountain of writing about Kennedy and the Kennedys, the mastering of which would require several scholarly lives. A good deal of it concerns in various ways the mythology that attaches to the subject matter, what with its abundant source materials of family, drama, legend, money, glamour, sex, crime, politics, charisma, disease, and, of course, unspeakable tragedy. A certain debunking is thus rightly part of that historiographical operation. ${ }^{4}$ I keep this mythologizing/demythologizing in mind but my purposes here are only indirectly related to that polarity. Kennedy's anti-imperialism in the I950s, meanwhile, has not been a central concern (or "problem") in the standard biographies but there have been some excellent accounts that do center on it. Mine will differ from them less in "what actually happened" than, as will be evident, in the framing and purpose of the argument. ${ }^{5}$

Second, historiography and myth aside, I do need to say something about the biographical context, not as "truth" but by way of indicating how I myself grasp Kennedy as a figure and in particular what I think is pertinent about his

${ }^{4}$ For reasons of space, references to the vast secondary literature will be kept to a minimum. Of the standard, sympathetic accounts, I have found especially useful Ted Sorensen, Kennedy (New York: Harper Perennial, 2009; first published 1965); and Robert Dallek, An Unfinished Life: John F. Kennedy, I9I7-1963 (New York: Back Bay Books, 2004). The classic debunking text, centering on Vietnam, is of course David Halberstam, The Best and the Brightest (New York: Random House, 1972), a book that should be reread periodically by all; and similarly Seymour M. Hersh, The Dark Side of Camelot (New York: Back Bay, 1998). On the earlier period, see Nigel Hamilton's JFK: Reckless Youth (New York: Random House, 1993), excessive but fun to read. Stephen Rabe, The Most Dangerous Area on Earth: John F. Kennedy Confronts Communist Revolution in Latin America (Chapel Hill: University of North Carolina Press, 1999) remains a devastating indictment. A recent, typically judicious synthesis is Alan Brinkley, John F. Kennedy (New York: Times Books, 2012).

${ }^{5}$ Thus Dallek in his authoritative and informative Life of 800 pages spends only a few paragraphs on the Algerian speech. Vietnam, because of what happened afterwards, has been more widely explored but the Algerian intervention in 1957 was more controversial and strongly pitched. See, first, the pioneering effort by Ronald J. Nurse, "Critic of Colonialism: JFK and Algerian Independence," The Historian, 39, 2 (1970), 307-26; later Jeffrey A. Lefebvre, "Kennedy's Algerian Dilemma: Containment, Alliance Politics and the 'Rebel Dialogue," Middle Eastern Studies, 35, 2 (1999), 61-82; and Theresa Romahn, "Colonialism and the Campaign Trail: On Kennedy's Algerian Speech and His Bid for the 1960 Democratic Nomination," Journal of Colonialism and Colonial History, I , 2 (2009). 
background. This brief account is not meant to "explain" his subsequent position but, more modestly, to suggest a range of conditions of possibility in which the social meets ideology. For the sake of concision, I will merely enumerate these aspects:

(i) Kennedy did not have to work for a living and never had a proper "job" except for some journalistic dabbling at the end of World War II. He did not even, perfunctorily, get the law degree requisite for the typical political career in the United States. His one sustained activity before Congress was his illustrious military service. The immensely wealthy, selfmade Joseph Kennedy Sr. (a more complex character than is generally understood) set his numerous progeny up to become "relatively autonomous," not to be idle rich certainly but to be able to devote themselves to something worthy beyond the drudgery of material worries. It was a clear concept of "independence" as absence of external determinants. JFK was always "outside" or at some remove from the social structure. ${ }^{6}$

(ii) Kennedy was the second son. In the typically hierarchical and gendered process, Joseph Sr. centered his overpowering hopes (the presidency, no less, lurking somewhere on the horizon) on his eldest son, Joseph Jr., whom he adored. Until his brother's death in 1944 on a near-suicidal air mission, JFK, sickly and a bit goofy, thus escaped the full intensity of paternal expectations. He was twenty-seven years old and still unclear about his "career" when the focus now shifted onto him. Two years later, in 1946, he was elected to the House of Representatives in a safe Boston seat engineered by his father. The upward trajectory from House to Senate and perhaps beyond was in the works from the beginning.

(iii) Kennedy, at forty-three famously the youngest elected President ever, had a stellar war record and exuded youth, vigour, virility and masculinity; but he was the most "physically challenged" person to enter the White House in the twentieth century, the possible exception being

${ }^{6}$ On Kennedy Sr. see David Nasaw, The Patriarch: The Remarkable Life and Turbulent Times of Joseph. R. Kennedy (New York: Penguin, 20 I 2). Empirically sound, Nasaw's book still has some difficulty with Kennedy as a character. Joseph, unlike his second son, was a materialist of reductionist persuasion: interests, mostly of a fairly crude kind, govern the world. Hence his oddly naive view that the Nazis could be bought off in 1938-39. After 1946, he kept a low political profile so as not to jeopardize John's career. His speech at Robert's law school (Virginia) in December I950 was an exception - worth a read for its unflinching attack on coldwar policies in the name of a retooled notion of "Fortress America." As he asked rhetorically, "what business is is it of ours to support French colonial policy in Indo-China or to achieve Mr. Syngman Rhee's concepts of democracy in Korea?" See Joseph P. Kennedy, "Present Policy Is Politically and Morally Bankrupt," Vital Speeches of the Day, 17, 6 (195 I), I 70-73. 
(though I doubt it) the essentially wheelchair-bound Franklin D. Roosevelt. With a multitude of chronic ills and illnesses, Kennedy was near death on several occasions and required an astonishing number of medications (liberally interpreted) to get through the day. It was, existentially, a life of being towards death.

(iv) Kennedy, as far as I can tell, was neither a particularly good Catholic nor a good Irish American, by which I mean that neither identity (or orientation) was constitutive. He fulfilled the role of both without hypocrisy when he was called upon to do so and it fit his purposes; but neither "function" was anything but a tradition, a reference and a given towards which one had to position oneself, depending on the circumstances. He kept a clear distance from that familiar figure, the Irish American politician, as personified by his maternal grandfather John Fitzgerald. Indeed, Kennedy was more at home (to the extent he ever was) in the salons of the English aristocracy than in the Irish wards of Boston. $^{7}$

(v) Kennedy was the best-read of the four brothers and the only one with "intellectual" interests, chiefly politics and history. He was not, however, an intellectual. ${ }^{8}$ Philosophical inquiry as such did not excite him. Nevertheless, he was capable of what one might call second-order reflection, thinking above the action about the conditions of that action. From his contemporary analysis of the British unwillingness to challenge Nazi Germany in the I930s to "the Burkean hero against the system" on display in the Profiles in Courage of the mid-r950s, the problem of

\footnotetext{
${ }^{7}$ Kennedy, while hailing the Irish nation for obvious reasons, never romanticized (unduly) Irish resistance, even at "Irish" occasions. See e.g. his remarks at the Irish Institute, New York, I 2 Jan. 1957, at www.jfklibrary.org/Research/Research-Aids/JFK-Speeches/Irish-InstituteNYC_I 9570 I I 2.aspx. With clear reference to recent events in Hungary, he pointed out that in the 17 th century "the Irish people were brutally slaughtered and enslaved by a ruthless and relentless Cromwell," following which the population declined by $50 \%$. The punchline - that the Irish eventually gained freedom as the Hungarians no doubt would - did not disguise the Cromwellian lesson of his remark. In the Senate debate on Poland in August 1957, indeed, he said that it had taken the Irish 700 years of disastrous rebellions to get to their goal, which was not a good recipe for the Poles. See Congressional Record, Senate, I03, I I (2 I Aug. 1957), I 5540 .

${ }^{8}$ Couve de Murville, who knew Kennedy at the time in Washington before he returned to France to become de Gaulle's foreign minister, called him retroactively "an intellectual," by which he meant "a man who reads, who thinks, and who believes that life is more complicated than it generally appears." See Maurice Couve de Murville, Oral History Interview - 5/20/1964, JFKL, at www.jfklibrary.org/Asset-Viewer/Archives/JFKOHMCDM-or.aspx. Given that laconic but expansive notion (intriguing in itself), I would agree he was an intellectual; but he did not fit the mould in any stricter sense. He was not interested in intellectual inquiry for its own sake.
} 
political will and historical limits is at the forefront.9 This kind of informed intelligence (as I think one can call it) is not always typical of Presidents.

(vi) Kennedy was also unusually well travelled. A good number of Presidents in the twentiethth century have had experience abroad but few (possibly Teddy Roosevelt) had the sustained "political" travels and extended stays that Kennedy had from the mid-1930s onwards. He travelled high and low and far beyond the Grand Tour of the typical upper-class, East Coast American. From early on, courtesy of his totally unabashed father, he would meet and converse with important people abroad. In mid1939, for example, one finds the twenty-two-year-old Kennedy in Jerusalem but also in Moscow.

(vii) Congress bored him, the Senate less so than the House, no doubt because members had more power and there was more about foreign relations, always his chief interest. Nonetheless, Kennedy took care of his political obligations and became, in time, an indefatigable, wellinformed and powerful campaigner, aided by a first-rate staff (which he could afford); by his brother Robert who turned out to be an equally first-rate campaign manager; and by his father's machinations with the media and important people. The political rise of JFK in the 1950 from inexperienced Representative to successful presidential candidate was nonetheless astonishing. He remains, one should recall, the only Catholic ever elected President. Given contingencies and (very) long odds, it is notable that he did not always play things in a politically "safe" way. The risks were certainly calculated to give the candidate-to-be deeper colours and sharper contours. The operation was nothing if not "instrumental." Still, his anti-imperialism, however calculated, was not only risky but also expressive of a relatively coherent way of thinking about history and the world.

(viii) Kennedy's "politics" remained ambiguously related, no doubt intentionally, to the archetypal coldwar liberalism one might think at first sight he embodied. He was never a Stevenson liberal. Here, as elsewhere, he preserved a certain license, a capacity for potential reversal and fluidity of motion. Eleanor Roosevelt had every right to suspect him. Kennedy was not interested in commitment to social blueprints or indeed dogma. He was interested in movement, energy,

9 John F. Kennedy, Profiles in Courage (New York: Perennial, 2004; first published 1956). He says, disapprovingly, by way of preface that the cold war had generated "rigid ideological unity and orthodox patterns of thought" (17). 
action and power, or, to put in another way, process as utopian transcendence.

From this abitrary list, I take as salient the detachment, a distancing operation that translates not into spectatorial passivity (obviously) but into a certain play and irony. It is analytical intelligence coupled with the will to win, where the very notion of the "race" is foundational.

Kennedy was assassinated at the very moment when the cold war, stricto sensu, was waning and arguably (at least I have so argued) turning into something else, thus raising the unanswerable question what he would have done in that novel conjuncture. I leave that problem aside, except to say, by way of negation, that he was not Lyndon B. Johnson. ${ }^{10}$ The cold war, meanwhile, is still debated as a periodizing device, though the conventional view that, in any case, the whole thing came to a resounding end with the end of the Soviet Union around 1990-9 I now reigns supreme from left to right. That problem, too, I will leave aside, except to point out that the focus on the existence of the Soviet Union for the concept of the "end" tends to produce a focus on the Soviet Union as the cause. My own view, for the record, is that the cold war was a US project: the weaker Soviets, with good reason, had no wish for it and tried clumsily to counteract its very structure. One might still argue that, whatever the intention, the ultimate "cause" of the cold war, what made the US put it into effect, was the actions of the Soviet Union (or the character of Joseph Stalin, etc. etc.). About the orthodox US view as it had crystallized by the early I950s, there is, however, less controversy since it was simple and liberally on exhibit. ${ }^{I I}$

It can be summarized briefly. The cold war was not only caused by the Soviet Union, it is the Soviet Union. Totalitarian Moscow, like its totalitarian Nazi relative, is inherently about world conquest. For the sake of necessity and convenience, the communist regime has chosen, unlike, the Nazis to accomplish its evil designs by means of cold rather than hot war. This, too, is, however, a war to death which can only end favourably with the end of the

${ }^{10}$ For better or worse: Johnson the bone-crushing deal-maker proved far bolder and more "activist" on domestic policy (witness the epochal reform year of 1965) than Kennedy, who was inclined to see limits and problems. Inversely, Johnson had none of Kennedy's confidence and knowledge about foreign policy. When push came to shove, Johnson was stuck in the shibboleths of the I950s. On the spectre of Vietnam, all I indicate in this essay is that there is no set answer and we might as well give that game up; though if I were pressed up against the wall for an answer, I would have to say that the idea of Kennedy sending half a million troops to Vietnam seems really far-fetched.

${ }^{11}$ I have stated this view on many occasions, in fully fledged form most recently in Anders Stephanson, "Cold War Degree Zero," in Joel Isaac and Duncan Bell, eds., Uncertain Empire: American History and the Idea of the Cold War (New York: Oxford University Press, 2012). 
Soviet regime itself. Real diplomacy in the traditional sense of "deals" is, in such circumstances, tantamount to appeasement, i.e. merely whetting the totalitarian appetite. Ultimately, the only legitimate deal one could make with the communists would concern the practicalities of their unconditional surrender. In the meantime, a vast preponderance of strength is necessary to keep Moscow expansionism at bay and the only power that can do that is, of course, the United States, leader of the free world, a domain defined in turn as that which is not communist. ${ }^{12}$

This is condensed, of course, but not a caricature. One needs to add that the functional point of the edifice is less the actual policy (or non-policy) towards the Soviet Union itself than the massive, global imperative to order and control "the free world." The power of the cold war as a project, the beauty in all its crudity, if you will, was that it makes uncontroversial US globalism. Given the unlimited, existential threat, there could be no limit to the response. The story of the I930s and World War II demonstrated this and the obverse errors of "isolationism" with the greatest clarity: "never again" and so forth. After 1948 and, say, the defeat of Henry Wallace, no one could gain any political traction, at least nationally, by challenging the basics of coldwar orthodoxy.

The trouble, alas, was that the threat may have been unlimited but the actual resources of the United States, however powerful, were not. And so, in 1949, Washington chose rightly not to intervene extensively in China to prevent the creation of the People's Republic. This and the ensuing, stalemated Korean War gave rise to a strategic and tactical controversy between Democrats and Republicans concerning "containment" and "liberation" which essentially turned on the efficacy and morality of just "stopping" the communists as opposed to actively destroying them in areas beyond one's own control. What is important about that debate, firmly situated within orthodoxy, is that it illustrated what one might call the coldwar deficit, viz. that the posited threat not only permitted any action anywhere, on principle, but also made determinate action, also on principle, morally and politically imperative. All things being equal, in short, one could never do enough. Orthodoxy, accordingly, opened up for the opposition to claim that the responsible in power were coming up short because they were in fact by definition coming up short. Hence the nasty Republican claims in the election campaign of 1952 that equated containment with appeasement. Hence the claims that Truman (or the spies in the State Department) had "lost" China. Hence also the claims

\footnotetext{
${ }^{12}$ No single document expresses this in full but NSC-68 of April 1950 comes close. Written by a committee of the Policy Planning Staff (and not as is often said by Paul Nitze, the presiding spirit), it remains the most ideologically charged condensation of the US position on the early cold war: true in its exaggeration.
} 
that there was a sorry lack of will to make use of nuclear superiority. ${ }^{13}$ Against this, the practical counterargument about essential/inessential came up distinctly short: if "freedom" is indivisible, what makes China any less important than Western Europe and possibly Japan? Why not indeed extend the Korean War into China, going nuclear if need be, and rid the world of the new communist regime?

As it turned out, once in power the Republicans also saw the logic of the ordering of essential "free-world" domains while avoiding any too offensive attacks on the evil empire, "liberation" (and "massive retaliation") more or less ending up as a more rhetorical version of containment. ${ }^{14}$ And so, having made the same Faustian deal as the Democrats, Republicans opened themselves up to the kind barrage of criticism for laxity of coldwar conduct that the young Senator John F. Kennedy would unleash on them towards the end of the I950s and leading up to his election in 1960.

Impatience with the sterilities of the cold war, then, took the predictable form here of "not doing enough" and "what is actually being done is wrong." Kennedy's alternative was more and better nuclear weapons, more and better ground troops, more and better everything, but also (in a simultaneous and typically contrary move) demand for a serious approach to negotiations, especially on arms control. Kennedy, notably, rejected explicitly the notion that negotiations were "appeasement," though he never pushed that point to challenge orthodoxy head-on. Most of all, however, Kennedy wanted two things which lay beyond substance: energetic leadership coupled with specificity and "flexibility" in policy. For the key notion in Kennedy's emergent posture was precisely flexible particularity over rhetorical generality: intelligent mastery in addressing actually existing problems rather than striking (as he saw it) politically safe poses. What was wrong with orthodoxy, then, was chiefly that it was a systemic constraint. ${ }^{\text {I5 }}$

${ }^{13}$ Kennedy, the young Democratic congressman, chimed in with some trite babble here in early 1949, blaming the State Department and the White House for the "disaster" in China and for relying on advice from "the Lattimores and the Fairbanks." Congressional Record, House, 95, I (25 Jan. I949), 532-33.

${ }^{14}$ This is not to say that nothing was ever done by way of "attacking" the Soviet Union and auxiliary regimes: the extent of the "psy-war" - including all manner of actions far beyond "the psychological" - was both varied and sustained. It is merely to say that the decisive aspect was always the globalist agenda with regard to the "free world."

${ }^{15} \mathrm{He}$ stated this to various degrees on many occasions. His speeches (and Senate interventions) are more incisive, not surprisingly, than his career-enhancing efforts in the mainstream media which tend to the bland, predictable and overly calculated. For synthetic statements in 1957 , see his "A Democrat Says the Party Must Lead - Or Get Left," Life, is March 1957, 164-77 (Kennedy was on the cover); and "A Democrat Looks at Foreign Policy," Foreign Affairs, 36, 
Nevertheless, if the coldwar deficit opened up for a predictable coldwar response, there was also a kind of "pragmatic break" with orthodoxy on substantial grounds. First, as we shall see, he used the cold war quite cleverly as a way of questioning the strategic viability of both containment and liberation as applied to Eastern Europe, saying in effect that successful execution of the cold war required that the basic coldwar scenario of black and white had to be adjusted to allow for grey, as not all "satellites" were alike. This thesis appealed to coldwar efficacy while actually eliminating one of its very foundations. Second, and more important, Kennedy reduced explicitly the scope of the cold war. Rather than an all-encompassing system, it became an aspect of the more fundamental conflict in world history between "imperialism" and "freedom." The most serious and challenging form of imperialism, to be sure, was the Soviet one; but, as he insisted in 1956, "the most powerful new force to shape the world since World War II" was "surging African-Asian nationalism," or, as he also called it, "the revolt against colonialism, the determination of people to control their national destinies"; and this development had nothing inherently to do with the cold war. The United States, because of misplaced abnegation before the narrow interests of European allies, had largely missed this revolutionary change. Home of the famous Declaration of Independence, the postcolonial United States had thus fallen into mealy mouthed "neutrality" in the struggle between Western imperialism and anticolonial emancipation and so, disturbingly, also opened up for the now dangerously agile, post-Stalinist Soviets to pose as the true friends of national liberation. Whereas neutrality between East and West was officially condemned as immoral, the United States itself, ironically, espoused the very same position in the struggles between North and South. ${ }^{16}$

Put differently, Kennedy was arguing that the United States had projected anticommunism beyond its proper domain, extending, negatively, the countering of communism promiscuously to conflicts and problems that had nothing as such to do with it. None of the four crises wracking the Mediterranean at the time, for example, had in his view anything intrinsically to do with

I (Oct. I957), 44-59. "Leadership" was a tactically useful theme but also essential to Kennedy's outlook, the substance of process, so to speak.

${ }^{16}$ On Eastern Europe, see reference below, note 31. For the quotations on decolonization and nationalism see his strong speech at the Los Angeles World Council, 21 Sept. 1956, www.jfklibrary.org/Research/Research-Aids/JFK-Speeches/Los-Angeles-CA-World-AffairsCouncil_19560921.aspx. See also "A Democrat Looks at Foreign Policy"; and his speech at the University of Pennsylvania, "The New Dimensions of American Foreign Policy," I Nov. 1957, www.jfklibrary.org/Research/Research-Aids/JFK-Speeches/Universityof-Pennsylvania_1957 I I I.aspx. On the irony of "neutrality" see his speech at Easter Oregon University, 9 Nov. 1959, in Strategy for Peace, 140. 
the struggle with communism or the Soviet Union: Suez, Cyprus, Israel and French North Africa. Still, he recognized the strategic difficulties:

We want our Allies to be strong, and yet quite obviously a part of their strength comes from their overseas possessions. And thus our dilemma has become a paradox. We want to keep the world free from Communist imperialism - but in doing so we hamper our efforts, and bring suspicion upon our motives, by being closely linked with Western imperialism. ${ }^{17}$

He was referring to the kind of posture (and policy) which marked the Truman and Eisenhower administrations alike: yes, colonialism is no doubt on the way out but, the cold war being absolutely decisive, it is essential that the process of decolonization be stable, gradual and above all orderly so as not to give the communists any openings, all of which makes it prudent for the United States, generally, to support properly supervised introduction, stepby-step, of Western-orientated, reformist leaders that would find it natural then to integrate their new nations in the free-world struggle against the global threat of totalitarianism; but, should that happy solution be unavailable, one might have to give extensive support to existing Western imperialism, especially in cases where the anticolonial opposition shows any communist flavour. ${ }^{18}$ Kennedy, by contrast, thought this would land the United States on the wrong side of history. The solution, dilemmas notwithstanding, was to take an unequivocal stand for the right to independence and let the proverbial chips fall wherever.

Exhibit A here, as it happened, was France. It was relatively easy to single out France, devoid of any constituency in the United States and saddled with extensive colonial wars in Vietnam and then Algeria. Kennedy knew a good deal about both wars and they formed the target of two of his most important sallies in the Senate. In the fall of $195 \mathrm{I}$, he had made an exhaustingly long trip together with Robert and his sister Patricia from Europe through the Middle East to South and Southeast Asia, ending up in Japan, where, once again, he almost died from illness. His stay in Indochina and Vietnam made a strong

\footnotetext{
${ }^{17}$ Speech at Los Angeles, 21 Sept. 1956; speech at Irish Fellowship Club, Chicago, I7 March I 956, www.jfklibrary.org/Research/Research-Aids/JFK-Speeches/Chicago-IL-Irish-FellowshipClub_i95603 17.aspx.

${ }^{18}$ I am simplifying, of course, and beneath the official surface even John Foster Dulles had a fairly clear idea of where the colonial question was heading. Nonetheless, the logic of the cold war did determine in the last instance. See the nuanced discussion in Robert B. Rakove, "A Genuine Departure: Kennedy, Johnson and the Non-Aligned World," unpublished dissertation, University of Virginia, 2009, chapter I. Typically, the Basic National Security Policy statement of 1956 dictated support for "constructive" nationalist movements and "orderly evolution of political arrangements toward self-determination" (quoted in ibid., 25); but the Eisenhower policy of pacts and alliances, in a larger sense anticommunism, gave priority to more important things than "self-determination."
} 
impression. ${ }^{19}$ The futility of the enormous French endeavour to defeat Viet Minh militarily was duly noted, as was the degree to which this effort was almost entirely underwritten by the United States. Once elected (1952) to the Senate, he made a serious attempt (1953) to stop US support for the sham, French-sponsored Bao Dai regime in Vietnam. His basic argument (he was strongly supported, interestingly, by Barry Goldwater) was simple: without "a crusading and reliable army" of Vietnamese, the struggle was hopeless; and there would be no such army without real independence, a real nation to defend. Hence the United States must tie any material support to the relinquishment of French sovereignty. ${ }^{20}$

A year later, when the epic disaster at Dien Bien Phu finally ended French rule, Kennedy wobbled a bit as the crisis narrowed, apparently, the choice either to the French or the Viet Minh: no viable "third force" could realistically be envisaged in May 1954. He was hazy on the solution but not on the egregious mistakes of the Eisenhower administration in its constant predictions of imminent victory and soon-to-be independence. "No amount of American military assistance in Indochina," he said, "can conquer an enemy which is everywhere and at the same time nowhere." ${ }^{21}$

${ }^{19}$ The notes I have seen specifically on Vietnam are not extensive but give an indication. There was dinner (no notes) with Bao Dai, the would-be "emperor," and a good deal of interaction with the French. Kennedy flew over the Hanoi Delta, fiercely fought over, with the French commander, Marshall de Lattre, whom he greatly respected. Kennedy grasped that Ho Chi Minh controlled most of the countryside and he also believed as "many Americans" in the area that the French could have avoided the overall problem by giving Indochina its independence after World War II. He also thought Asian "leadership" here would recast the conflict from one "between native communists and western imperialists, between the white and the yellow man," to "a struggle to preserve Asiatic democracy and the independence of native governments against the new imperialism of the communists." His conclusion was clear: "The support of the legitimate aspirations of the people of this area against all who seek to dominate them - from whatever quarter they may come." JFKL, Pre-presidential Papers, Box o I I, Boston Office Files, Speech Files 46-52, "Far Eastern Trip, I95 I." Throughout this trip, he met important individuals (from Ben-Gurion to Nehru). Curiously, in view of the times, the Indian foreign minister told him that the Chinese, being indepdendent-minded, would part ways with Moscow, but not if there was continued, compact resistance to them from everyone else. What prevented any opening (Kennedy reflected) was, however, the required Western concessions: recognition, of course, and a series of other measures that were essentially a gamble and exceedingly difficult. See http://archive2.jfklibrary.org/JFKPP/o I / JFKPP-o I I-0I7/JFKPP-o I I-0 I7-poo36_lres.jpg.

${ }^{20}$ Kennedy's chief statement on Indochina, 30 June 1953, will be found in Congressional Record, Senate, 99, 6 (1953), 7622-25. See also the debate i July i 953, ibid., 7780-84.

${ }^{21}$ For Kennedy's varying statements on the emerging and intensifying crisis from March to May I 954 see Congressional Record, Senate, I00, 3 (1954), 2904; ibid., 100, 6, 4671-81 (quotation at 4673); speech at Cook County Democratic Dinner, 20 April 1954, www.jfklibrary. org/Research/Research-Aids/JFK-Speeches/Chicago-IL-Cook-County-Democratic-Dinner I 9540420. aspx; speech at Princeton University, I I May 1954, www.jfklibrary.org/Research/ Research-Aids/JFK-Speeches/Princeton-University_I95405 I I.aspx; speech at St. Michael's 
So much better, in any case, that the eventual partition Kennedy had dreaded turned out, unexpectedly, to permit not only the formation of an independent republic (it was thought) south of the i 7 th parallel, but one led by a Catholic to boot, a regime thus deserving wholehearted US support. For the rest of the 1950s, Kennedy thus believed, or allowed himself to believe, in the properly nationalist and reformist credentials of the Diem regime; and he was indeed to play a role in "the Vietnam Lobby." ${ }^{22}$ Nevertheless, he was fully aware of Ho Chi Minh's stature as a national (if not necessarily nationalist) fighter against the Japanese and the French, and in 1954 he believed the communist would win open elections. Indeed, in the wake of Dien Bien Phu, he expressed respect (in suitably guarded language) for the way the insurgents had "instilled into their people a philosophy that shows itself in the most extraordinary acts of dedication and self-sacrifice." ${ }^{23}$

"Dedication and self-sacrifice" were in fact precisely qualities of the kind Kennedy himself liked to invoke but found lacking in both the "cynical" West and the chillingly "neutralist" Asia. Individualized qualities of this type are often privileged in Kennedy's outlook. Yet, again, one must also recognize the "structural" element. The cold war was an integral part, but only a part, of the world-historical struggle for national independence. Hence (ran one unspoken corollary) the center of the universe was not the Atlantic or the "transatlantic relationship." Moreover, democracy and national liberation as a project

College, VT, I6 May i954, www.jfklibrary.org/Research/Research-Aids/JFK-Speeches/StMichaels-College-VT_i9540516.aspx.

${ }^{22}$ See his panglossian address to the "Friends of Vietnam," the organized lobby, on I June 1956: www.jfklibrary.org/Research/Research-Aids/JFK-Speeches/Vietnam-ConferenceWashington-DC_19560601.aspx. Kennedy complained wrongly that Vietnam after the dramatic turn for the better had disappeared from US media - it was actually covered, if not extensively, the New York Times reporting censorship and arrests at the same time as it editorially expressed support for the Diem regime and US aid (see is Feb., I I March, I I April, and, after Kennedy's speech, 2 July 1956). Kennedy then issued a truly appalling ode to Diem and his regime. "Vietnam represents the cornerstone of the Free World in Southeast Asia, the keystone to the arch, the finger in the dyke... Where once a playboy emperor ruled from a distant shore, a constitutent assembly has been elected. Social and economic reforms have likewise been remarkable. The living conditions of the peasants have been vastly improved, the wastelands have been cultivated, and a wider ownership of the land is gradually being encouraged. Farm cooperatives and farmer loans have modernized an outmoded agricultural economy; and a tremendous dam in the center of the country has made possible the irrigation of a vast area previously uncultivated. Legislation for better labor relations, health protection, working conditions and wages has been completed under the leadership of president Diem." He knew better. Ironically, he also noted that, historically, the Vietnamese had resisted and stopped Chinese expansion in the region; so, presumably, he would not have been surprised in 1979 when the two communist powers went to war.

${ }^{23}$ Quotation from speech at St. Michael's College, I6 May I 954; also his Senate speech, 30 June 1953; and his Senate speech on 6 April 1954, Congressional Record, Senate, 100, 4 (1954), $467 \mathrm{I}-8 \mathrm{I}$. 
entailed no preordained, constitutive place for "free enterprise," a Western or perhaps even American notion that was largely meaningless for the deprived and brutalized peasant masses of the colonial world. Western democracy and capitalism were, if you will, site-specific, the result of several centuries of development not easily reproduced or even possible elsewhere. ${ }^{24}$

If Vietnam was a tricky issue for Kennedy because of the communist leadership of the national liberation struggle, Algeria provided a much easier "case." Front de libèration nationale (FLN) was demonstrably not communist and Kennedy, from 1956 onwards, learnt about it extensively through personal contacts, partly with central Tunisian figures in Washington. ${ }^{25}$ The difficulty with Algeria (or at least with the three northernmost départements) was that, technically, it was part of metropolitan France and, again technically, the United States recognized this. Whenever the issue came up in the UN from I 955 onwards, France would insist that it was an internal matter and so not a UN concern. The United States supported this, despite some typical mumbles and misgivings. The United States also supported, de facto if not explicitly, the massive military operation comprising several hundred thousand troops that the French, now out of Indochina, launched in 1956. Above all, the United States provided its NATO ally with military matériel. ${ }^{26}$ Kennedy, as in Indochina, wanted the US to insist on independence for the colony, indeed to quit accepting the French pretence that Algeria was not a colony in the first place.

The Suez crisis, however, complicated matters for him: Eisenhower's decisive action against the Anglo-French and Israeli operation in October

${ }^{24}$ On "site-specificity" see among other statements his speech at Rockhurst College, Kansas City, 2 June 1956, www.jfklibrary.org/Research/Research-Aids/JFK-Speeches/RockhurstCollege-MO_19560602.aspx; his speech at University of Florida, Gainesville, i 8 Oct. 1957, www.jfklibrary.org/Research/Research-Aids/JFK-Speeches/University-of-Florida-Banquet_ I 957 I 0 I 8.aspx.

${ }^{25}$ Two sources were Habib Bourguiba Jr. (very briefly) and, above all, Mongi Slim, who served as combined Tunisian ambassador to the US, the UN and Canada. Yet I think Kennedy, helped out on French materials by Jacqueline, always kept an eye on the problem of French colonialism because of the fiasco in Indochina.

${ }^{26}$ The specific references to Kennedy and Algeria in note 5 aside, see more generally (from a variety of perspectives) Egya N. Sangmuah, "The United States and the French Empire in North Africa, 1946-1956: Decolonization in the Age of Containment," unpubl. PhD diss., University of Toronto, 1989; Daniel Byrne, "Adrift in a Sand of Sand: The Search for United States Foreign Policy toward the Decolonization of Algeria, 1942-1962," unpubl. PhD diss., Georgetown University, 2003; Irvin Wall, "The United States, Algeria, and the Fall of the Fourth French Republic," Diplomatic History, I 8, 4, 489-5 I I; Matthew Connolly, $A$ Diplomatic Revolution: Algeria's Fight for Independence and the Origins of the Post-Cold War Era (New York: Oxford University Press, 2002). Sangmuah's account is especially clear on the lacklustre result of trying to maintain a favourable view of decolonization in principle while hanging on to a coldwar frame. 
I 956 seemed to fit well - too well - the spirit of his own concepts at the same time as, conversely, he was committed for political (and other) reasons to Israel. Furthermore, the United States and the Soviet Union found themselves, momentarily and awkwardly, rather on the same side in the UN. So Kennedy said relatively little about this and nothing at all about Israel's role. ${ }^{27}$ Eisenhower then helped him out in early 1957 by recharging coldwar orthodoxy in the region in announcing what became known as his Doctrine: anticommunist aid to regimes in the area and, implicitly, serving geopolitical notice that Arab "nationalism," at least in its Nasserist form, was under suspicion. On 2 July, in any case, Kennedy gave his "Algerian speech" in the Senate, probably the single most important one he ever gave in that congregation. He himself invested it with tremendous significance, printing up and distributing beforehand thousands of copies. It was a long and didactic effort which outlined his general position on "imperialism" and his specific one on Algeria, viz. the United States had to stop being neutralist on colonialism and take a stand in favour of national independence, recognizing that Algeria was no internal French matter which Paris would somehow resolve in good faith. Nothing in recent imperial French history indicated so. ${ }^{28}$

One might wonder why, as an emerging candidate for the Democratic nomination in 1960, he chose to make Algeria such a prominent issue. The Algerian imbroglio was known and debated in "informed circles," if nothing else for the good Eurocentric reason that it was destabilizing the Fourth Republic and detracting from the cold war; but it was scarcely in the thick of things. The answer, ultimately, is not known. Several "instrumental" reasons

${ }^{27}$ On the background for Kennedy's support for Israel see Warren Bass, Support Any Friend: Kennedy's Middle East and the Making of the U.S.-Israeli Alliance, New York: Oxford University Press, 2003), chapter I. In 1956, Kennedy gave a couple of pandering speeches, the second on account of Golda Meir's visit right after Suez, where he says blandly that "the complexities of the present turmoil" will not diminish consideration for Israel. When he did address those "complexities" they did not include any reflection on Israel's place in the Suez sequence. See www.jfklibrary.org/Research/Research-Aids/JFK-Speeches/Boston-MAGolda-Meir-Dinner_I 956 I I 25.aspx; and his earlier Yankee Stadium address, www.jfklibrary. org/Research/Research-Aids/JFK-Speeches/Yankee-Stadium_19560429.aspx. It is noteworthy that, between these two speeches, he also observed the influence of national lobbies: "The conduct of our policies with respect to Israel, Ireland, Greece, Italy, Poland, and others will be determined more by the political potency of nationality groups in this country than by the stricter requirements of our national interest as a whole." See his address to the Los Angeles World Council, 2 I Sept. 1956, www.jkklibrary.org/Research/Research-Aids/JFKSpeeches/Los-Angeles-CA-World-Affairs-Council_i 956092 I.aspx.

${ }^{28}$ The speech and the debate will be found in Congressional Record, 103, 8 (2 July 1957), 10780-93. This is the best place to read it since it includes the surrounding remarks and the debate. The jolly atmosphere, controversy notwithstanding, is striking. It is (by current standards) remarkable how chummy the senators are across the dividing lines. Kennedy restated his position succinctly in the Jesuit journal America, 5 Oct. 1957, I 5-17. 
can be adduced. He happened to know the question and it offered a relatively risk-free way of making a splash, thus improving his stature in foreign relations. Having kept a low profile on the anything but risk-free struggle over civil rights at home, he used Algeria and his concern with Africa as a symbolic way of shoring up his standing among Afro-Americans. Abundantly aware of the potency of Richard M. Nixon as a coming rival, Kennedy was peremptorily staking a certain claim: in early 1957, Nixon had gone on a wide tour of Africa, occasioned by the celebration of Ghana's independence, and Kennedy knew well that Nixon was one of the few major figures who actually shared his interest in Africa and indeed was not so far from his own position. ${ }^{29}$ The speech, as it turned out, earned him no great gains at home. He was roundly castigated by the Establishment (e.g. the New York Times, Time magazine, Dean Acheson and, in remarkably unequivocal words, Adlai Stevenson). French authorities expressed extreme displeasure, the FLN and sympathetic forces strong support. ${ }^{30}$

The speech may well have been calculated for expedient reasons (how could it not?) and probably all the ones given above. However, a more interesting "instrumental" question in the present context is the degree to which it was meant, if at all, to be a more efficient way to fight the cold war. There was certainly an alert in that sense to the functional danger of continuing existing policy. In a dissolving Algeria, "moderate people become extremists, extremists

${ }^{29}$ See references above in note 5 for various versions of the instrumental reasons. Clearly, it was meant to gain attention and reinforce his stature as a potential candidate but that is hardly surprising. On Nixon, see Byrne, ch. 5; and Thomas D. Matijasic, "It's Personal: Nixon, Liberia and the Development of U.S. African Policy," White House Studies, I I, I (20 I I), 39-55.

${ }^{30}$ Dean Acheson rapped him across the knuckles, more or less intimating that he was an immature twit, and so Acheson went on to support Johnson in the early campaign of 1960. "Nothing can be more injudicious than this proposal except making it," was his characteristic verdict on Kennedy's speech (New York Times, 26 Oct. 1957). The Times (3 July 1957), in more polite language, took pretty much the same view. Time magazine (is July i957) ridiculed him in a cartoon as a boy in shorts setting off a fire cracker under the properly attired and diplomatic John Foster Dulles. More surprising was Adlai Stevenson's view. Coming back from a trip to Africa, Stevenson praised France, Britain and even the Belgians (!) for their "great advances in education, industrial and economic developments" (New York Times, 9 July 1957). A little later he excluded North Africa from the frame (ibid., I7 July 1957), though he also said independence would mean chaos (ibid., 30 July 1957). The speech generated a very large response in correspondence, many exceedingly critical, the FLN jubilant. See John F. Kennedy, Pre-presidential Papers, JFKL, Senate Files, "Algerian Speech Files," Box 919. Kennedy defended himself forcefully. In one interesting passage, he denied that he harboured any "dogmatic faith that nationalism, merely by its proclamation, deserves American support" as there were indeed "retrogressive, reactionary forms of nationalism." This, then, was a reason to support Algerian independence before it was taken over by either Communist or "reactionary Islamic forces." Kennedy to John Harriman of the Boston Globe, n.d. (but probably August 1957). 
become revolutionaries, and revolutionaries become Communists." The argument then seems to turn on an empirical disagreement within the mainstream frame, viz. "contrary to Establishment views, the revolutionary movement in Algeria is precisely the kind of moderate nationalist government in the making that we say we want and consider future members of the free world proper, and this, relatively speaking, is more important than the problem of metropolitan France and the French settlers. In fact, this will help France in the long run and so help us to fight the cold war in Europe." Kennedy said as much and it would have been silly not to. However, he retained his "partial" concept of the cold war and the separate, autonomous process of decolonization and national liberation. Fundamentally, he insisted that these events were external to the cold war as such and should not primarily be evaluated in coldwar terms. In short, he did not derive the logic of support from the logic of the cold war.

The distinction becomes clearer when one considers that the month following the Algeria speech there was the intentionally symmetrical "Polish speech." This did pertain to the anti-imperialist struggle of the cold war, the struggle that was in a way the cold war. Kennedy was asking how the bankrupt strategies vis-à-vis the subjugated sphere of Eastern Europe might be changed. "Liberation," the Republican and supposedly activist alternative to Democratic containment, had achieved nothing, its emptiness amply and painfully demonstrated the previous year during the Soviet suppression of the Hungarian revolt when the United States issued rhetorical support and rhetorical support only. Intriguingly, as already indicated, Kennedy's coldwar alternative was, in effect, "less by way of cold war." He wanted to change the indiscriminate trading laws regarding Eastern Europe to allow for de facto openings to "nationalist" (or national-leaning) communist regimes such as Władysław Gomulka's in Poland. Success in encouraging, within the Soviet sphere, a measure of national independence could only be achieved by forgetting (so to speak) the rigidities of anticommunism and by concentrating on nonideological practices of trade and exchange. The map of Eastern Europe was not uniform and it was myopic, consequently, to treat all "satellites" identically. "There can be shades of gray between these blacks and whites," he said, "a limbo or twilight zone between complete Soviet domination ... and a free, friendly government - a nationalist Communist government such as is evolving in the case of Poland." A predictable debate about the morality of aiding and abetting the enemy ensued but the speech proved not nearly as controversial as the Algerian predecessor. In both cases, however, Kennedy's organizing principle was "national independence" versus imperialism or empire. ${ }^{31}$

${ }^{31}$ See Congressional Record, I03, I I (2 I Aug. 1957), 15446-54. The rubric was in fact "The Anti-imperialist Struggle, Part II." 
Meanwhile, alas, the bracketed Soviet Union refused to play the role of inanimate object. The post-Stalinist regime in Moscow was leaving behind Stalin's continental isolationism for a variegated, erratic activism, not least in the emergent third world. More pressingly, on 4 October 1957, six weeks after Kennedy's Polish speech, the Soviets stunned the world and the United States in particular by propelling into orbit an actual satellite, the first in history. The Sputnik was tiny but the rocket that put it up there was not. The cold war would turn into a "race" and not only in terms of arms.

From the fall of 1957 to the advent of his presidency, John F. Kennedy, always ready to race, became increasingly fixated on competing with the Soviet Union. This required an account not only of the competitor but also of the competitiveness of the United States itself. This became a problem, then, that spanned the domestic and the foreign. More fundamentally, it also put into question the nature of the race. This is hard to sort out, but competing with the Soviet Union, "the race," was not necessarily the same as fighting the cold war more intensively and effectively, though this is the way, inevitably, it was received and understood.

It is difficult for us today to imagine the Soviet Union as a promising and even attractive model of modernity. In the late I950s it was not very difficult at all. Kennedy was impressed and worried about its growth rates; he was impressed and worried about its technological achievements, its educational and scientific focus; and he was impressed and worried about its capacity to mobilize its collective resources and intelligence for instrumental purposes, the very toughness of the system. While the United States made Edsels, the Soviets made Sputniks; while the United States was wallowing in consumer goods, comforts and luxury, the Soviets were concentrating on the real stuff. And he worried a great deal that it would be a logical and inviting model for the emergent nations in the third world, as it seemed to offer "the glamour of novelty, a disciplined, coherent, and irresistible answer to the overwhelming problems of economic management and progress." Translating this competition onto two analogues, he also worried, extensively, that the People's Republic of China was edging ahead of India. As if this were not enough, he found himself thinking that Nikita Khrushchev appeared to be more flexible and agile in his outlook than John Foster Dulles. ${ }^{32}$

${ }^{32}$ These concerns come to the fore on numerous occasions, not least in the election campaign speeches of 1960. Here is a representative sample: speech at University of Pennsylvania, I Nov. 1957, www.jfklibrary.org/Research/Research-Aids/JFK-Speeches/University-ofPennsylvania_1957Iror.aspx; speech at National Conference of Jews and Christians, 
How, indeed, a system he also described, in more baffled moments, as akin to that of ancient Egypt could do all this, Kennedy could not explain or chose prudently not to ponder. Nor did he explore how one kind of imperialism, the Western version, could be doomed to the world-historical dustbin while the other might very well be on the historical rise. What was clear, however, was that the United States would have to "prove that we can devote as much energy, intelligence, idealism and sacrifice" for the open society "as the Russian despots can extort by compulsion." 33

Toughness, efficiency and technological prowess, reflecting assumed Soviet virtues, could easily be integrated mirror-like into the coldwar axiomatic, the proverbial coldwar deficit: "We are not doing enough to meet the threat, we are falling behind in missiles, bombers, education, engineering, etc. etc." Indeed, the complex of ills fit exactly and so, irresistibly, Kennedy now found himself reinforcing orthodoxy. The constitutive gap, he intimated, was in fact widening: a new, much more flexible and vigorous regime in Moscow corresponded inversely to the platitudinous, predictable and stolid Eisenhower administration, whose stiff anticommunism and commitment to massive retaliation seemed to translate, oddly, into a mixture of timidity and laxity, generating (as his election rhetoric of 1960 would have it) nothing but "dust, dullness, langour, and decay." 34 A political terrain was opening up, then, that was ideally suited to the appearance of bouncy, young, activist Kennedy in contrast to the decrepit, old and passive Eisenhower. The polarity, at once

Chicago, 3 Dec. 1957, www.jfklibrary.org/Research/Research-Aids/JFK-Speeches/NationalConference-of-Christians-and-Jews_1957 I 203.aspx; speech at Knights of Columbus, South Boston, I 2 Jan. I958, www.jfklibrary.org/Research/Research-Aids/JFK-Speeches/SouthBoston-MA_i9580II2.aspx; speech at University of New Hampshire, Durham, NH, 7 March 1960, www.jfklibrary.org/Research/Research-Aids/JFK-Speeches/University-ofNew-Hampshire_19600307.aspx. Finally, see his speech in the Senate, Congressional Record, 106, Io (1 4 June 1960), I 2523-29. His "A Democrat Looks at Foreign Policy" in Foreign Affairs describes the inflexibility of John Foster Dulles; his speech at Rochester, I Oct. 1959, says that Nikita Khrushchev "is shrewd, he is tough, he is vigorous, well informed, and confident," and, moreover, "not the prisoner of any ancient dogma or limited vision" (Strategy for Peace, 34). The quotation is from a speech at B'Nai Zio, New York, 9 Feb. 1959, in Strategy for Peace, 156.

${ }^{33}$ Speech at University of New Hampshire, Durham, NH, 7 March 1960, www.jfklibrary.org/ Research/Research-Aids/JFK-Speeches/University-of-New-Hampshire_1 $9600307 . a s p x$. This is perhaps the place to say a word about "modernization." In a larger sense, this was what Kennedy had in mind and he was, by late 1957, certainly influenced by Max Milliken and Walt Rostow's powerful account of this. Neverthelss, one should be wary of any simple equation here. Kennedy thought the model too economistic (as it were). My own view, slightly discordant, is that he saw fairly clearly that this kind of approach might rather easily become a new dogma, a new ideology of closure. On this generally see Michael Latham's now classic Modernization as Ideology: American Social Science and "Nation-Building" in the Kennedy Era (Durham: University of North Carolina Press, 2000).

${ }^{34}$ Introduction to Strategy for Peace, 28. 
political and iconographic, became the center of Kennedy's persona, its condition of possibility. The operation was exceedingly successful. Nixon, only four years older and very young by presidential standards (forty-seven), unfairly appeared even in sympathetic coverage to belong to a stale and stodgy world of yesteryear, an awkward and solitary figure against the already famously rich, glamourous, athletic and perpetually grinning Kennedy clan.

All of which is well known and endlessly pursued. Kennedy even scored easy points on Nixon's putatively frivolous "Kitchen Debate" with Nikita Khruschchev, ridiculing his rival for privileging colour televisions over success in space. 35 What interests me here, however, is again how the polarity served to push Kennedy in the direction of orthodoxy. Notably (and characteristically), he extended the thematic of "intelligent, flexible activism" to the domain of arms control, criticizing, rightly, the Eisenhower administration for its lack of any realistic program in that regard; and his campaign book in 1960 was, after all, entitled Strategy for Peace. Still, his "peaceful" move was subordinate to the overarching line that only by redressing "the balance" elsewhere into that safe and more comfortable preponderance of power that was essentially US hegemony, or even supremacy, could real progress be made. ${ }^{36}$

To this one can then add that the shifting terrain in the third world, indeed the very transformation of the colonial world into "the third world," was also conducive to coldwar activism. Contrary to what any informed observer in the West might have said in 1945 , colonialism in world-historical terms as well as actual politics was dead as a doornail already by 1960 , when seventeen new states came into being in Africa alone. The war in Algeria, to be sure, was still grinding on; but with the advent of the Fifth Republic and Charles de Gaulle's assumption of power in May 1958, Kennedy chose to acquiesce in the official US hope, a pleasing one, that in due course the general would resolve the problem by granting independence. ${ }^{37}$ The question of the third world, in any case, was now less about support for national liberation than about how one

${ }^{35}$ Speech at High School Stadium, Alexandra, VA, 24 Aug. 1960, www.jfklink.com/speeches/ jfk/aug60/jfk240860_rally.html. Kennedy brought up the Kitchen Debate on several occasions in a derisory sense - to which one must add that the view imputed to Nixon about consumerism seems to give him the final laugh here.

${ }^{36}$ His Senate speech on 14 June 1960 is a good summary. It is also notable for its heavily disguised trial balloon on doing something new with regard to the People's Republic of China. Overall, he seems to have thought about the difference between the Soviet Union and the PRC as a matter of stages: the former had come out of its Stalinist one while the latter was going through it. He also seems to have imagined, but not in any sustained way, an emerging, multipolar world of diversity and heterogeneity. Congressional Record, I 06, io ( 14 June 1960), I 2523-29.

${ }^{37}$ See Irvin Walls's acerbic “De Gaulle, the 'Anglo-Saxons,' and the Algerian War," Journal of Strategic Studies, 25, 2 (2002), i I 8-37, for an excellent corrective which reveals de Gaulle's highly malleable position. 
might compete with the Soviets geostrategically on this new terrain. While the European theatre (Berlin always excepted) had settled into a war of position, borders and zones more or less set by tacit agreement, the third world opened up, in orthodox terms, for a war of movement.

And there the argument might then conveniently stop. Emerging as a viable presidential candidate in a political conjuncture conducive to dynamic prosecution of the cold war, Kennedy fulfilled that historic role with gusto. We know the rest.

A more satisfactory or at least open-ended end will require some additional reflection on "the utopian deficit" (as I like to think of it), and on what it is to "race." Kennedy's impatience with coldwar orthodoxy featured constantly the problem of "leadership," both presidential and US in the world. Evidently, this was largely about being intelligently "active" in contrast to the torpor, real and imagined, of the Eisenhower administration-movement as opposed to stagnation. The positive notion that the United States inherently must be the "leader" (to be the United States is to be the leader) was negatively dramatized by the now apparent threat of losing that pre-eminence in a variety of ways to the Soviet counterpoint. At a deeper level, that dark scenario was about a certain loss of transcendence. Kennedy was irritated by the fact that third-world leaders read and were inspired by Marx rather than Thomas Jefferson, author of the Declaration of Independence. ${ }^{38}$ (The Virginian, of course, was also a large-scale owner of Afro-American slaves, which may have impeded African enthusiasm for him; but this aspect did not enter Kennedy's vision.) An element of resentment, even envy, is in any case discernible in his account of the new communist support for third-world anti-imperialism and national liberation.

If the Eisenhower administration thus lacked inspirational overcoming of the real, coming up with nothing better than Nixon's dishwashers, Kennedy's desire had to do with militance (not the same as militarism), sacrifice,

${ }^{38}$ See e.g. speech at State Capitol at Albany, 29 Sept. 1960, www.jfklibrary.org/Research/ Research-Aids/JFK-Speeches/Albany-NY_i 9600929 .aspx. Or, in the same spirit, "There is not a present American statesman who is quoted by any African leaders today." Speech at Government Square, Cincinnati, 6 Oct. I 960, www.jfklibrary.org/Research/Research-Aids/ JFK-Speeches/Cincinnati-OH-Government-Square_19601006.aspx. On occasion, he would refer to Franklin D. Roosevelt and Woodrow Wilson as contrast. By "utopian," in any case, I mean something along the lines of Fredric Jameson's theorization, not the notion of a readymade plan for an alternative, future society but an intrinsic part of the ideological operation. From that starting point, one might indeed go on in Jameson's spirit to "map" Kennedy's dilemmas and closure by means of the semiotic square that he, in turn relying on Algerdiras Greimas, tends to favour: more work to be done, I think. One place to start would be Fredric Jameson, Archaeologies of the Future: The Desire Called Utopia and Other Science Fictions (London: Verso, 2005). 
collective mobilization as well as individual bravado, breaking new ground, certain heroism, if you will: the famous "burdens" and the crossing of "new frontiers." The injunction "to lead" was accordingly more than a competitive necessity, it was a regenerative process that would restore to the United States its rightful identity as the home of the future, its aura of utopian transcendence: "let us put a man on the Moon within ten years," and so on. It helped, of course, that the mythological Kennedy himself in every way personified this utopian transcendence.

It will be remarked at once, and correctly, that this desire, or fantasy, was masculine to the core, Teddy Roosevelt redux, nothing but an updated version of Progressivism circa I 900 . The focus on process and conduct, the Weberian adequation of means and ends, the importance of study and particularity, the nonideological commitment to state action and improvement, the deep belief in regenerative deeds and selfless sacrifice, the emphasis on masculine physicality and fitness: it is all there. Historical antecedents aside, however, the question remains how this played out in the specific conjuncture of the late I 950 and coldwar orthodoxy. 39

The obvious answer has already been given: more and better efforts to meet the threat. This argument, generally, was still in 1960 indisputable and so a winner. Nonetheless, this was not, say, I 948: "the threat" was different. On the one hand, it was more dangerous on more levels (missiles, developmental model); on the other, it was also precisely about being a model in a competition rather than one of two forces in a posited (mutually lethal) confrontation, however abstract. The assumption of "war" in the coldwar matrix was, one must recall, no mere metaphor: the Soviet Union and its auxiliary communists were by definition a condition of war, a force bent on world conquest. To oppose it was, therefore, conceptually speaking, to engage in combat and to win that combat, that war, was ultimately to destroy the threat. The Soviet Union, the threat, was axiomatic, the derived need for global US action likewise so. The space for dissent and debate, to reiterate, was thus restricted to the appropriateness of the US counterstrategy, archetypal containment versus liberation, but in fact amounting in both cases to putting the Soviet Union in brackets while organizing the noncommunist universe known as "the free world."

This was ideology as closure. Decolonization and the emerging third world threatened to crack that closure, rendering simple anticommunism difficult, if not unworkable. Kennedy's solution was to restrict the cold war and invent a positive "American" concept for this new site: postcolonial (US) support for

39 The central article on the gender aspect is Robert D. Dean's great "Masculinity as Ideology: John F. Kennedy and the Domestic Politics of Foreign Policy," Diplomatic History, 22, I (1998), 29-62. The emphasis on the Progressive analogue is more my own. 
decolonization and national liberation. Ingeniously, he also revised the coldwar matrix itself by turning the Soviet empire into a series of varied regimes on a scale from black to grey. By raising, too, the more fundamental utopian deficit, however, he was putting into question (evidently) the character of the United States itself, its very fitness, as it were. In the Soviet Union, no longer bracketed, he recognized a competitor in a race, a worldhistorical race, to be sure, but a race nonetheless. Such an event required the United States to live up to its billing, to prove its mettle. Hence his litany of ills after 1957 went far beyond the standard formula of "not doing enough to cover the coldwar deficit" - he was asking why Eisenhower's United States was falling short of being the United States, why it was not being true to its utopian credentials.

It would be wrong to think this just a reinforced and invigorated version of the orthodox matrix. For the world-historical race course is not a fight to the death or unconditional surrender except in the sense that the Soviets themselves imagined their system to be superior and would win out in the long run. Such a competitive setting involved, ironically, greater intensity by way of real action in the imaginary race to the finishing line: the third world as a "site" stimulated greater real competition. ${ }^{\circ}$ This is why Kennedy launched into his several third-world initiatives with such enthusiasm: Alliance for Progress, Peace Corps, aid to advertise that the United States was indeed a progressive model; but also counterinsurgency, Green Berets, fierce and abiding support for sundry repressive regimes and other relentlessly pursued, supposedly intelligent strategies of "specificity," including the preposterous obsession with the figure of Fidel Castro.

That the race took this form and in this space was of course not unrelated to the advent of mutually assured destruction, the identity and recognition encapsulated in the devastating fact of nuclear terror. As far as the direct relationship was concerned, the obviousness of the mutual interest in stability and predictability would have to await the hair-raising experience of the Cuban missile crisis, an existential moment of truth if there ever was one. There followed the Test Ban Treaty and the beginning of a "managed relationship." That none of this, coldwar orthodoxy or not, made any difference in real life to the Vietnamese peasant south of the 17 th parallel is another story.

Still, here as elsewhere one should never forget Kennedy's detachment, his fluidity and (let us say) his sense of dialectical movement in history. Beyond the greatness of deeds, he was not locked into any ideology - ideology conventionally understood as a coherent, explicit, normative position. His

${ }^{40}$ This is where Odd Arne Westad's notion of the cold war in a global context as residing, in intensive form, in the third world comes into new light, and perhaps our disagreement could turn more interesting. 
24 Anders Stephanson

discomfort and irritation with coldwar orthodoxy was precisely that it was orthodoxy: correct opinion and received wisdom, closure, stifling action, bold and new. What that action might be was subject to change, sudden possibilities requiring unorthodox ways of thinking and, of course, vigorous leadership with the ability to master the particular and the contingent. Kennedy, in his better moments, was willing to contemplate doing otherwise, if not actually doing it in the end. 